\title{
Analisis Deiksis Bahasa Kutai di Kecamatan Muara Muntai Kabupaten Kutai Kartanegara Provinsi Kalimantan Timur
}

\author{
Rosita Rosita, Asnan Hefni, Endang Dwi Sulistyowati \\ Universitas Mulawarman \\ Universitas Mulawarman \\ Universitas Mulawarman \\ Email: rositarose290@gmail.com
}

\begin{abstract}
This research aims to describe the type, shape, and function of the cyclical deiksis of Kutai language in Muara Muntai District of East Kalimantan Province. Data analysis techniques are organized in several steps, namely data reduction, data presentation, and conclusion withdrawal. Based on the results of data analysis, it was found that the type of cyclical system of Kutai language consists of persona deiksis, place decission, and time decisity. The decyclical form of Kutai language persona is divided into three, namely the first pronomina that refers to oneself, the second pronoun that refers to the speaker to the interlocutor, and the third pronoun that is the person being talked about. A form of place decisis as a gift of form to a place in a language event. The form of decyclical time giving the form of expression time is done in speech. The function of decises is divided into three, namely, the function of decission persona includes as a pointer to belong, as the subject, as an object, is a function that is found in many studies. The decyclical function where use in research leads a lot as a place description indicator. The decyclical function of time in this study shows the description of time.
\end{abstract}

Keywords: deixis, kutai language.

\section{PENDAHULUAN}

Bahasa

digunakan

untuk

mengungkapkan ide, gagasan, isi pikiran dan realitas. Bahasa juga berperan penting dalam bidang komunikasi, terutama komunikasi antarmanusia, baik secara langsung maupun tidak langsung. Bahasa itu manasuka (abritrer), bahasa itu vokal atau bahasa itu merupakan sistem bunyi, bahasa itu simbol, bahasa itu mengacu pada dirinya, bahasa itu manusiawi, dan bahasa itu komunikasi. Dengan bahasa, manusia dapat berkembang dan mengabtraksikan berbagai gejala yang muncul di lingkungannya.

Bahasa memiliki peran penting dalam kehidupan manusia. Tanpa bahasa manusia tidak akan bisa berkomunikasi. Sebagai makhluk sosial manusia senantiasa ingin berhubungan dengan manusia lain. Ia ingin mengetahui lingkungan sekitar, bahkan ingin mengetahui apa yang tadi dalam dirinya. Rasa ingin tahu ini memaksa manusia perlu berkomunikasi.

Jelaslah bahwa bahasa sangat penting peranya dalam kehidupan sosial. Komunikasi akan berjalan dengan lancar apabila sasaran bahasa yang digunakan tepat, artinya bahasa itu digunakan sesuai dengan situasi, kondisi penutur, dan sifat penuturan itu dilaksanakan. Hal ini bergantung pada faktor-faktor penentu dalam tindak bahasa atau tindak komunikasi yaitu lawan bicara, tujuan pembicara, masalah yang dibicarakan, dan situasi. Penggunaan bahasa seperti inilah yang disebut pragmatik.

Djajasudarma (2012: 48) menjelaskan bahwa pragmatik adalah studi yang mencakup interaksi antara pengetahuan kebahasaan dan dasar 
pengetahuan tentang dunia yang dimiliki oleh pendengar/pembaca. Pragmatik mengkaji lima hal yaitu deiksis, peranggapan, tindak tutur, implikatur, dan struktur wacana. Deiksis adalah suatu kajian pragmatik yang merupakan gejala semantik yang terdapat pada kata-kata atau konstruksi yang dapat ditafsirkan acuannya dengan memperhitungkan situasi pembicaraan yang jelas.

Istilah deiksis berasal dari bahasa Yunani Kuno yaitu deiktikos yang bermakna "hal menunjukan secara langsung, berpindah atau berganti-ganti" tergantung pada siapa yang menjadi pembicara dan tempat dituturkannya katakata itu. Kata-kata seperti saya, kamu, dan dia, merupakan kata-kata yang bersifat deiktis, rujukan kata tersebut barulah dapat diketahui siapa, di mana, dan pada waktu kapan kata-kata itu diucapkan.

Peristiwa deiksis dapat terjadi pada bahasa lisan maupun tulisan, dapat pula berupa deiksis persona, deiksis tempat, dan deiksis waktu. Kata-kata deiksis pada setiap bahasa jumlahnya terbatas. Walaupun demikian, sistem deiksis justru termasuk yang sangat sulit dipelajari orang yang bukan penutur asli bahasa yang bersangkutan. Dalam memahami dan menentukan sebuah ujaran bersifat deiksis atau tidak tentu membutuhkan pemahaman yang menyeluruh. Salah satu aspek penting dalam menganalisis pemakaian bahasa adalah maksud pembicara. Maksud pembicara sangat ditentukan oleh konteks penutur. waktu. dan tempat.

Sistem deiksis bahasa yang satu dengan bahasa yang lain adalah berbeda. Hal ini dikarenakan tiap-tiap bahasa memiliki kaidah bahasa dan latar belakang budaya tersendiri yang berbeda dengan kaidah latar belakang budaya bahasa yang lain.

Deiksis persona adalah pemberian bentuk kepada peran peserta dalam kegiatan berbahasa. Dalam kategori deiksis persona yang menjadi kriteria adalah peran peserta dalam peristiwa berbahasa itu. Peran dalam kegiatan berbahasa itu dibedakan menjadi tiga macam, yaitu persona pronomina pertama, persona kedua, dan persona ketiga. Kata-kata deiksis persona pada setiap bahasa jumlahnya terbatas.

Deiksis Tempat adalah pemberian bentuk lokasi menurut peserta dalam peristiwa bahasa. Levinson (Nadar, 2013: 55) menjelaskan deiksis tempat berhubungan dengan pemahaman lokasi atau tempat yang dipergunakan peserta tuturan dalam situasi penuturan. Deiksis tempat yang berhubungan erat dengan sebuah konsep jarak, yaitu tempat hubungan anatar orang dan bendanya ditunjukkan.

Deiksis Waktu adalah pemberian bentuk pada rentang waktu seperti yang dimaksudkan penutur dalam peristiwa bahasa. Levinson (Nadar, 2013: 56) menjelaskan deiksis waktu menunjukan keterikatannya dengan kata tense dan adverbial penanda waktu. Kita dapat melakukan kejadiankejadian waktu sebagai objek yang bergerak kearah kita (ke dalam pandangan) atau bergerak menjauh dari kita (luar pandangan).

Bahasa Kutai merupakan salah satu bahasa daerah yang turut memperkaya khazanah bahasa Indonesia, baik dalam kosa kata maupun bentuk kata. Bahasa Kutai merupakan salah satu bahasa dari beratus-ratus bahasa daerah di Indonesia dan merupakan bahasa daerah paling banyak dipakai dan sangat luas jumlah penuturnya di Kalimantan Timur, yang meliputi Kabupaten Kutai Kartanegara, Kutai Timur, Kutai Barat, Paser, Samarinda, Balikpapan, dan Bontang, kategorilah penutur bahasa Kutai terbanyak di Kalimantan Timur karena berdasarkan sejarah Kerajaan Kutai, hampir semua wilayah Kalimantan Timur dulunya berada dalam kekuasaan kerajaan Kutai, sehingga disepakati menggunakan bahasa Kutai sebagai bahasa pemersatu pada zaman itu.

Dalam penelitian ini, terpilihnya Kecamatan Muara Muntai Kabupaten Kutai Kartanegara sebagai tempat penelitian. Kecamatan Muara Muntai terletak di Kabupaten Kutai Kartanegara Provinsi Kalimantan Timur. Muara Muntai yang dihuni pada sekitar abad 19, antara lain oleh suku Kutai, dan kemudian oleh Bugis, Jawa, dan Dayak memiliki sejarah panjang di mana kota ini merupakan sebuah wilayah kecil yang mandiri di bawah Kerajaan Kutai Marta Ing Dipura.

Sebagaimana halnya bahasa-bahasa daerah yang lain, bahasa Kutai di Kecamatan Muara Muntai juga mengemban fungsi-fungsi ideal, yaitu sebagai lambang identitas dan kebangaan, sebagai sarana komunikasi, dan sebagai pemerkaya bahasa Indonesia. Namun, fungsi-fungsi secara perlahan mengalami penunman, terutama pada generasi sekarang. Salah satu permasalahan yang dihadapi adalah penelitian bahasa Kutai di Kecamatan Muara Muntai yang masih terbatas.

Selama ini penelitian terhadap bahasa Kutai di Kecamatan Muara Muntai yang pernah dilakukan masih terbatas mengenai struktur linguistiknya, di antaranya Suryadikara, dkk. Tahun 1997, dalam kajiannya yang berjudul "Struktur Bahasa Kutai". selanjutnya dilakukan penelitian terhadap "Deiksis Persona dalam 
Bahasa Melayu Kutai Tenggarong" pada tahun 2015.

Kajian-kajian pragmatik dan sosiolinguistik yang masih kurang atau minim khususnya bahasa Kutai di Kecamatan Muara Muntai sehingga belum cukup untuk menggali informasi keunikan bahasa tersebut. Oleh karena itu, dipandang perlu untuk melakukan penelitian terhadap bahasa Kutai di Kecamatan Muara Muntai sebagai salah satu upaya pelestarian bahasa daerah agar tidak punah dan peneliti juga melihatnya banyaknya tuturan bahasa Kutai yang berbentuk deiksis dalam tuturan masyarakat. Salah satunya kajian atau penelitian mengenai deiksis sendiri.

Penelitian tentang deiksis bukanlah merupakan penelitian awal. Sebelum penelitian ini sudah ada penelitian lain, tapi penelitian ini berbeda dengan penelitian terdahulu. Perbedaannya penelitian ini dititikberatkan pada bentuk, jenis, dan fungsi dalam tuturan bahasa Kutai pada masyarakat Muara Muntai yang ada di Kabupaten Kutai Kartanegara Provinsi Kalimantan Timur yang lebih difokuskan lagi pada masyarakat yang ada di Kecamatan Muara Muntai. Jenis, bentuk, dan fungsi deiksis dalam tuturan yang akan dibahas meliputi deiksis persona. waktu. dan tempat.

Berkaitan dengan hal tersebut yang akhirnya mendorong untuk melakukan penelitian Analisis Deiksis bahasa Kutai di Kecamatan Muara Muntai Kabupaten Kutai Kartanegara Provinsi Kalimantan Timur sebagai tugas akhir perkuliahan. Hal ini dilakukan untuk mengetahui jenis, bentuk, dan fungsi deiksis dalam bahasa Kutai.

Adapun permasalahan yang menjadi kajian dalam penelitian ini yaitu, Bagaimanakah jenis, bentuk, dan fungsi deiksis bahasa Kutai di Kecamatan Muara Muntai Kabupaten Kutai Kartanegara Provinsi Kalimantan Timur.

Tujuan penelitian ini adalah untuk mendeskripsikan jenis, bentuk, dan fungsi deiksis bahasa Kutai di Kecamatan Muara Muntai Kabupaten Kutai Kartanegara Provinsi Kalimantan Timur.

\section{METODE PENELITIAN}

Dalam penelitian ini pendekatan menggunakan kualitatif. Pendekatan kualitatif adalah suatu pendekatan investigasi karena biasanya untuk mengumpulkan data dengan cara bertatap muka langsung dan berinteraksi dengan orang-orang di tempat penelitian. Menurut Syamsudin (2006: 74) tujuan dari penelitian kualitatif adalah untuk menganalisis yang diteliti agar diperoleh informasi mengenai perilaku mereka, perasaannya, keyakinan ide, bentuk pemikiran, serta dapat menghasilkan sebuah teori.

Dalam penelitian ini peneliti menggunakan metode observasi, metode wawancara, metode rekam,metode transkip, metode terjemahan, dan metode dokumentasi. Sedangkan teknik analisis data menggunakan metode analisis sebelum memasuki lapangan dan analisis selama di lapangan.

\section{HASIL DAN PEMBAHASAN}

Dengan menggunakan teori deiksis dari Yule, berikut uraian hasil analisis deiksis yang terdapat dalam bahasa Kutai di Kecamatan Muara Muntai Kabupaten Kutai Kartanegara Provinsi Kalimantan Timur.

\section{Deiksis Persona}

\section{Data 1}

Deiksis Persona Pronomina Pertama

Tunggal

$A k u$

$A k u$ nade tahu mana nuju

Terjemahan: Saya tidak tahu kemana pergi

Kutipan pada data 1 dalam bahasa Kutai

aku ialah yang mengacu orang pertama yaitu kategori rujukan pembicara kepada dirinya atau

kelompok yang melibatkan dirinya.

Data 2

Deiksis persona pronomina pertama jamak Kami

Kami nade tahu ge apa ngenai kanak tu nangis

Terjemahan: Kami tidak tahu juga apa yang membuat anak itu menangis.

Pada kutipan data 2 dalam bahasa Kutai

kata kami jenis deiksis persona pertama

jamakyang merujuk pada pembicara dan orang lain pihaknya.

Deiksis persona pronomina kedua

Deiksis persona kedua tunggal

Kau

Data 3

Kau bile hak lagi beleki?

Terjemahan: Кати kapan lagi bersuami?

Pada kutipan data 3 dalam bahasa Kutai

kata kau ialah merupakan jenis deiksis persona pronomina kedua tunggal, yaitu rujukan pembicara kepada seorang pendengar ujaran.

Deiksis persona pronomina kedua jamak

Kita 
Data 4

Uje urang kita dah pupus molahkan gubeng

Terjemahan: Kata orang kalian sudah selesai membuat perahu

Pada kutipan data 4 dalam bahasa Kutai kata kita ialah merupakan jenis deiksis persona pronomina kedua jamak, yaitu rujukan pembicara kepada seorang pendengar yang hadir bersama orang petama atau lebih.

Deiksis persona pronomina kedua jamak

Kita

Data 5

Uje urang kita dah pupus molahkan gubeng

Terjemahan: Kata orang kalian sudah selesai membuat perahu

Pada kutipan data 6 dalam bahasa Kutai kata kita ialah merupakan jenis deiksis persona pronomina kedua jamak, yaitu rujukan pembicara kepada seorang pendengar yang hadir bersama orang petama atau lebih.

Data 7

Ie ndek makan

Dia mau makan

Pada kutipan data 7 dalam bahasa Kutai kata ie ialah merupakan jenis deiksis persona pronomina ketiga tunggal, yaitu rujukan kepada orang yang bukan pembicara atau pendengar ujaran itu, baik hadir maupun tidak.

Deiksis persona pronomina ketiga jamak

Side

Data 8

Side tadi rame mlarai urang beklahi

Mereka tadi ramai melerai orang berkelahi

Pada kutipan data 8 dalam bahasa Kutai kata side ialah merupakan jenis deiksis persona pronomina ketiga jamak yaitu rujukan kepada orang yang bukan pembicara atau pendengar ujaran itu, baik hadir maupun tidak.

b. Deiksis tempat

Saneh

Data 9

Andek hak di meja saneh makanannya

Taruh saja di meja sana makanannya

Pada kutipan data 9dalam bahasa Kutai kata saneh ialah merupakan jenis deiksis tempat yang menunjukan konsep tentang jarak serta berhubungan dengan tempat.

\section{Deiksis waktu}

Empai

Data 10

Empai hak ku alak beju ku

Terjemahan: Besok saja ku bawakan

Bajuku

Pada kutipan data 10 dalam bahasa

Kutai kata empai ialah merupakan jenis

deiksis waktu yang menunjukan pemberian pada jarak waktu dalam peristiwa bahasa saat tuturan dibuat.

Fungsi dari deiksis persona yang terdapat dalam bahasa Kutai di Kecamatan Muara Muntai kabupaten Kutai Kartanegara Provinsi Kalimantan Timur dapat dilihat sebagai berikut.

1) Sebagai Penunjuk Kepunyaan

Fungsi deiksis sebagai penunjuk kepunyaan dalam berkomunikasi sehari-hari $a k u$ sering dipendekkan menjadi $k u$, apabila $k u$ berfungsi sebagai kependekkan dari $a k u$ maka ditulis terpisah di depan kata yang mengikutinya, seperti dalam kalimat berikut.

Data 11

Suruh iye ngalak jukut pijaku di rakit

Suruh dia pergi mengambil ikan asin $k u$ di rakit

Kutipan data 11 dalam bahasa Kutai kata pijaku merupakan fungsi deiksis persona pronomina tunggal sebagai penunjuk kepunyaan atau kepemilikkan.

2) Sebagai Subjek

Fungsi untuk menyatakan sebagai subjek ialah deiksis persona menjadi pelaku tindakan dalam kalimat. Pronomina persona $a k u$ dapat berposisi pada subjek maupun objek dalam kalimat, seperti dalam kalimat berikut.

Data 12

Aku nade tahu mana nuju

Saya tidak tahu kemana pergi

Kutipan data 12 dalam bahasa Kutai kata a $k u$ merupakan fungsi deiksis persona pronomina pertama tunggal sebagai subjek pelaku tindakan dalam kalimat.

3) Sebagai Objek

Fungsi untuk menyatakan objek ialah yang menyatakan objek dalam deiksis persona menjadi 
penderita dalam kaliamat, seperti dalam kalimat berikut.

Data 13

Segelenya tu gere-gere ie

Semuanya itu gara-gara dia

Kutipan data 13 dalam bahasa Kutai kata ie merupakan fungsi deiksis persona pronomina ketiga tunggal sebagai objek.

4) Sebagai Penunjuk postpositif

Fungsi untuk menyatakan sebagai penunjuk ialah yang berkaitan dengan kata sifat yang diletakkan setelah kata benda, didalam masyarakat Muara Muntai tuturan tersebut tidak ditemukan dalam proses komunikasi.

Penggunaan deiksis tempat yang berfungsi sebagai penunjuk keterangan tempat dapat dilihat sebagai berikut.

1) Sebagai penunjuk keterangan tempat

Fungsi pertama deiksis tempat dalam

bahasa Kutai yakni sebagai penunjuk keterangan tempat ialah deiksis tempat yang menunjukan keterangan tempat dalam suatu tuturan yang dekat, sebagai berikut.

Sini

Data 14

Coba kau ke sini

Coba kamu ke sini

Kutipan data 14 dalam bahasa Kutai kata sini merupakan fungsi deiksis persona tempat sebagai penunjuk keterangan tempat.

Penggunaan deiksis tempat yang berfungsi sebagai penunjuk keterangan tempat dapat dilihat sebagai berikut.

2) Sebagai penunjuk keterangan tempat

Fungsi pertama deiksis tempat dalam

bahasa Kutai yakni sebagai penunjuk keterangan tempat ialah deiksis tempat yang menunjukan keterangan tempat dalam suatu tuturan yang dekat, sebagai berikut.

Situ

Data 15

3) Sebagai penunjuk merujuk pada tempat yang jauh dengan penutur secara eksplisit.

Saneh

Data 16

Andek hak di meja saneh makanannya

Taruh saja di meja sana makanannya
Kutipan data 16 dalam bahasa Kutai kata saneh merupakan fungsi deiksis persona tempat sebagai penunjuk jarak tempat.

Fungsi deiksis waktu merujuk pada saat tuturan penggunaan kata dilakukan merujuk pada waktu sebelum ataupun masa lampau serta sesudah saat tuturan berlangsung, sebagai berikut.

1)Fungsi pertama deiksis waktu

Fungsi pertama deiksis waktu dalam bahasa Kutai merujuk pada saat tuturan yang ditandai dengan penggunaan, sebagai berikut:

Mini

Data 17

Mini ge bantui aku ke pasar

Sekarang juga bantu saya ke pasar

Kutipan data 17 dalam bahasa Kutai kata mini merupakan fungsi deiksis persona waktu sebagai menunjukan keterangan waktu saat tuturan.

Data 18

Cepati alak'i aku mini ge

Cepat jemput saya sekarang juga

Kutipan data 18 dalam bahasa Kutai kata mini merupakan fungsi deiksis persona waktu sebagai menunjukan keterangan waktu saat tuturan.

\section{Data 19}

Tadi ada undangan urang mini ge suruhnya pegi

Tadi ada undangan orang sekarang juga perginya

Kutipan data 19 dalam bahasa Kutai kata mini merupakan fungsi deiksis persona waktu sebagai menunjukan keterangan waktu saat tuturan.

\section{KESIMPULAN}

Berdasarkan analisis dan hasil penelitian yang penulis peroleh, maka dapat disimpulkan sebagai berikut.

Bentuk deiksis persona dalam bahasa Kutai di Kecamatan Muara Muntai Provinsi Kalimantan Timur bervariasi dan memiliki acuan yang berbeda-beda tergantung pada peran peserta tutur dan pembicara (penutur) dan pendengar (petutur). Penggunaan sistem deiksis dalam tindak komunikasi merujuk pada penggunaan jenis, bentuk, dan fungsinya. 
Pronomina persona bahasa Kutai di Kecamatan Muara Muntai Kabupaten Kutai Kartanegara Provinsi Kalimantan Timur terdiri dari pronomina persona pertama tunggal yang dalam bahasa Kutai terdiri dari aku, sedangkan dalam bentuk jamak pada pronomina persona pertama yakni kami dan etam. Pronomina persona kedua tunggal terdiri dari kau, nyawa dan kita, sedangkan untuk bentuk jamak pada pronomina persona kedua ini yaitu kita. Pronomina persona ketiga tunggal juga terdiri dari ie, sedangkan untuk bentuk jamak pada pronomina persona ketiga ini yaitu side.

Fungsi deiksis persona yaitu: (1) Sebagai penunjuk kepunyaan Fungsi deiksis sebagai penunjuk kepunyaan alam berkomunikasi seharihari aku sering dipendekkan menjadi ku. (2) Sebagai subjek fungsi untuk menyatakan sebagai subjek ialah deiksis persona menjadi pelaku tindakan dalam kalimat. Pronomina persona aku dapat berposisi pada subjek maupun objek dalam kalimat, seperti dalam kalimat berikut. (3) Sebagai objek fungsi untuk menyatakan objek ialah yang menyatakan objek dalam deiksis persona menjadi penderita dalam kaliamat tersebut. (4) Sebagai penunjuk postpositif fungsi untuk menyatakan sebagai penunjuk ialah yang berkaitan dengan kata sifat yang diletakkan setelah kata benda, didalam masyarakat Muara Muntai tuturan tersebut tidak ditemukan dalam proses komunikasi.

Deiksis tempat yang mengacu pada bentuk lokasi atau tempat dari lokasi peserta dalam peristiwa bahasa, seperti sini, situ, dan saneh.

Penggunaan deiksis tempat memiliki beberapa fungsi yaitu sebagai penunjuk keterangan tempat, sebagai penunjuk merujuk pada tempat yang agak jauh dari pembicara dan sebagai penunjuk merujuk pada tempat yang jauh dengan penutur secara eksplisit. Dalam bahasa Kutai di Kecamatan Muara Muntai Kabupaten Kutai Kartanegara yang sering ditemukan adalah sebagai penunjuk keterangan tempat.

Deiksis waktu ialah pengungkapan atau pemberian bentuk pada titik jarak atau waktu yang dipandang dari waktu sesuatu ungakapan yang dibuat. Bentuk deiksis waktu yang terdapat dalam peristiwa bahasa masyarakat di Kecamatan Muara Muntai ialah empai, meriantu, kela, minggu dudi, mini, dan setumat.

Penggunaan deiksis waktu dalam bahasa Kutai memiliki fungsi yang menunjukan keterangan waktu, maksudnya ialah deiksis waktu yang menjelaskan keterangan waktu. Fungsi deiksis waktu merujuk pada saat tuturan penggunaan kata dilakukan merujuk pada waktu sebelum ataupun masa lampau serta sesudah saat tuturan berlangsung.

\section{REFERENSI}

Djajasudarma, Fatimah. (2012). Wacana dan Pragmatik. Bandung: PT. Refika Aditama.

Nadar, F.X. (2013). Pragmatik dan Penelitian Pragmatik. Yogyakarta:Graha Ilmu.

Nababan, PNJ. (1987). Ilmu pragmatik (Teori dan Penerapannya). Jakarta: PPLPTK

Sugiyono. (2018). Metode Penelitian Kuantitatif Kualitatif dan R\&D. Bandung: Alfabeta. 